\title{
Microalgae Polysaccharides: An Overview of Production, Characterization, and Potential Applications
}

\author{
Jorge Alberto Vieira Costa ${ }^{1, *}$, Bárbara Franco Lucas ${ }^{1}\left(\mathbb{C}\right.$, Ana Gabrielle Pires Alvarenga ${ }^{2}$, Juliana Botelho Moreira ${ }^{2}(\mathbb{D}$ \\ and Michele Greque de Morais ${ }^{2}$ \\ 1 Laboratory of Biochemical Engineering, College of Chemistry and Food Engineering, Federal University of \\ Rio Grande, P.O. Box 474, Rio Grande 96203-900, RS, Brazil; barbarafranco_eng@hotmail.com \\ 2 Laboratory of Microbiology and Biochemistry, College of Chemistry and Food Engineering, Federal \\ University of Rio Grande, P.O. Box 474, Rio Grande 96203-900, RS, Brazil; \\ anaggalvarenga@gmail.com (A.G.P.A.); julianapvi@yahoo.com.br (J.B.M.); \\ migreque@yahoo.com.br (M.G.d.M.) \\ * Correspondence: jorgealbertovc@gmail.com
}

check for updates

Citation: Costa, J.A.V.; Lucas, B.F.; Alvarenga, A.G.P.; Moreira, J.B.; de Morais, M.G. Microalgae

Polysaccharides: An Overview of Production, Characterization, and Potential Applications. Polysaccharides 2021, 2, 759-772. https://doi.org/ 10.3390 /polysaccharides2040046

Academic Editors: Cédric Delattre, Paolina Lukova and Guillaume Pierre

Received: 25 August 2021

Accepted: 23 September 2021

Published: 1 October 2021

Publisher's Note: MDPI stays neutral with regard to jurisdictional claims in published maps and institutional affiliations.

Copyright: (c) 2021 by the authors. Licensee MDPI, Basel, Switzerland This article is an open access article distributed under the terms and conditions of the Creative Commons Attribution (CC BY) license (https:// creativecommons.org/licenses/by/ $4.0 /)$.

\begin{abstract}
Microalgae and cyanobacteria are photosynthetic microorganisms capable of synthesizing several biocompounds, including polysaccharides with antioxidant, antibacterial, and antiviral properties. At the same time that the accumulation of biomolecules occurs, microalgae can use wastewater and gaseous effluents for their growth, mitigating these pollutants. The increase in the production of polysaccharides by microalgae can be achieved mainly through nutritional limitations, stressful conditions, and/or adverse conditions. These compounds are of commercial interest due to their biological and rheological properties, which allow their application in various sectors, such as pharmaceuticals and foods. Thus, to increase the productivity and competitiveness of microalgal polysaccharides with commercial hydrocolloids, the cultivation parameters and extraction/purification processes have been optimized. In this context, this review addresses an overview of the production, characterization, and potential applications of polysaccharides obtained by microalgae and cyanobacteria. Moreover, the main opportunities and challenges in relation to obtaining these compounds are highlighted.
\end{abstract}

Keywords: cyanobacteria; exopolysaccharides; functional activities; microalgal cultivation; nutrient limitation; rheological properties

\section{Introduction}

Microalgae and cyanobacteria are photosynthetic microorganisms that have been attracting attention due to their versatility in producing biomass that can be transformed into several products of high commercial value. These organisms can produce compounds including polysaccharides with antioxidant, antibacterial, and antiviral properties [1-4]. Porphyridium sp. [5], Chlorella sp. [2], Spirulina sp. [3], and Nostoc sp. [6] have been studied to produce polysaccharides.

Microalgal polysaccharides are described as being mainly heteropolysaccharides generally related to other components such as sulfates $[7,8]$. The synthesis and production of polysaccharides is a complex process, and their composition will depend on the microalgae strain and cultivation conditions such as the availability of nutrients, salinity, irradiance, and temperature. The extraction and purification of polysaccharides must be carried out aiming to reach high yields, without any other compounds, such as salts and proteins. Optimization of the steps from the cultivation of microalgae to polymer obtention have been studied by several researchers, aiming to achieve higher process yields [5,9].

Among the polysaccharides from microalgae, exopolysaccharides are highlighted [10]. Microalgal exopolysaccharides can be found solubilized in medium (released polysaccharides) or attached to cells (cell-bound polysaccharides) [5,11]. During microalgae cultivation, greater exopolysaccharide accumulation can be achieved by applying nitrogen 
limitation. The application of microalgae exopolysaccharides has surpassed the research phase, being currently applied in cosmetics [10,12]. Within this context, this review aims to provide an overview of the production, characterization, and potential applications of polysaccharides obtained from microalgae and cyanobacteria. Furthermore, the main opportunities and challenges concerning obtaining these biocompounds are highlighted.

\section{Polysaccharides from Microalgae}

Microalgae are organisms that have been used for decades as a source of nutrients by humans and animals. These microorganisms also contribute to mitigating negative impacts on the environment caused by non-environmentally friendly technologies [1,13]. The main advantage of microalgae/cyanobacteria is the possibility of them being cultivated using solar energy, wastewater, particulate materials (thermoelectric fly ashes), and gaseous effluents as a source of nutrients, without the need for arable land [14,15]. Furthermore, these microorganisms are recognized for their high composition of bioactive compounds, such as polyunsaturated fatty acids, phycocyanin, carotenoids, peptides, and polysaccharides $[1,16]$. Research shows that polysaccharides from microalgae and cyanobacteria may have antioxidant, antiviral, and antibacterial activities $[2,4,17]$.

Polysaccharides from microalgae can be divided into intracellular and structural (which includes exopolysaccharides released in the medium, cell-bound polysaccharides, and cell wall polysaccharides) [5]. Polysaccharides are polymers formed by long chains of monosaccharides. Depending on the monosaccharides present throughout the chain and the type of bond involved, a different polysaccharide with a specific structure and composition is formed [10].

Microalgal exopolysaccharides are synthesized during microalgal cultivation due to normal physiological processes or stress conditions [9]. Specific extraction and purification steps will be necessary according to the type of polysaccharide to be extracted and the condition of microalgae cultivation; centrifugation and filtration are frequently used processes (Figure 1) [10,11]. Exopolysaccharides can be recovered from the culture medium, resulting in the valorization of the process. Recently, studies have suggested the application of microalgal polysaccharides in nutraceuticals, food development, and as a bioflocculant [5,10,18,19] (Figure 1).

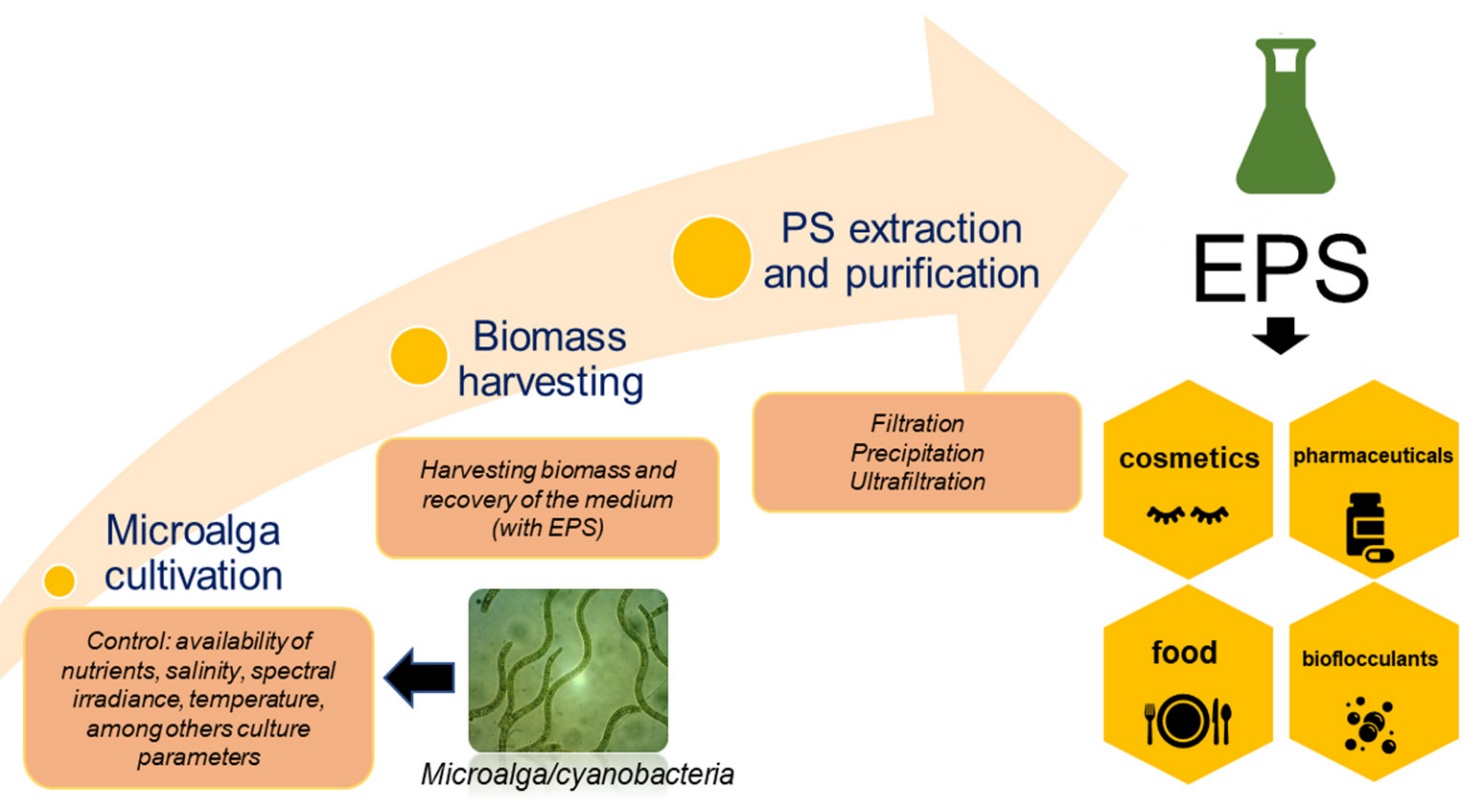

Figure 1. Steps for the obtention of exopolysaccharides (EPS) from microalgae and cyanobacteria cultures and their potential applications. 


\section{Influential Parameters in the Production of Polysaccharides by Microalgae}

Mixotrophic cultivations have been reported for polysaccharide production by Neochloris oleoabundans $\left(1 \mathrm{~g} \mathrm{~L}^{-1}\right)$ [20] and Arthrospira platensis $\left(0.30 \mathrm{~g} \mathrm{~L}^{-1}\right)$ [21]. Glucose and sucrose can be used as carbon sources to promote the accumulation of exopolysaccharides by Chorella sp. $\left(0.03 \mathrm{~g} \mathrm{~L}^{-1}\right)$ [22]. In addition to carbon, nitrogen, phosphorus, sulfate, residual metal solutions (calcium, magnesium, and iron) and vitamins are constituent nutrients in culture medium. However, when aiming at the production of a polysaccharide, special attention is given to nitrogen and phosphorus [9].

Limiting the nutrient supply is a commonly used strategy to increase the polysaccharides' accumulation by microalgae [9]. However, the microalgal growth and the biomass concentration can be reduced under these conditions. Therefore, ideal cultivation conditions that stimulate biomass production (nutrients supply, optimal temperature and luminosity, among others) combined with adverse growth parameters (stress conditions) are imposed to promote the polysaccharides' production [23,24]. Moreover, two-stage cultivations can be applied, where in the first stage, the microalga is cultivated in replete conditions of nutrients, providing greater biomass production. The second stage is usually carried out through nutrient deprivation/limitation to increase the polysaccharide content by microalgae [9]. Thus, it is possible to achieve high yields of microalga polysaccharides combined with high biomass productivity.

\subsection{Nitrogen Source and Salinity}

Nutritional optimization has been used to increase the production of exopolysaccharides by microalgae and cyanobacteria [25-32] (Table 1). Lupi et al. [26] evaluated the synthesis of exopolysaccharides by Botryococcus braunii UC58 cultivated under different nitrogen sources (nitrate, ammonium, and urea). The authors found that high concentrations of these compounds $\left(2.5 \mathrm{~g} \mathrm{~L}^{-1}\right)$ occurred with nitrate as a nitrogen source.

Table 1. Parameters affecting the production of polysaccharides from microalgae and cyanobacteria during cultivation.

\begin{tabular}{|c|c|c|c|c|c|c|}
\hline \multirow[t]{2}{*}{ Microalga/Cyanobacteria } & \multirow[t]{2}{*}{ Reactor } & \multirow{2}{*}{$\begin{array}{l}\text { Culture Medium } \\
\text { Composition }\end{array}$} & \multicolumn{2}{|c|}{$\begin{array}{l}\text { Polysaccharide } \\
\text { Production }\end{array}$} & \multirow{2}{*}{$\begin{array}{l}\text { Growing Condition } \\
\text { (Temperature and } \\
\text { Light Intensity) }\end{array}$} & \multirow[t]{2}{*}{ Reference } \\
\hline & & & $\mathrm{g} \mathrm{L}^{-1}$ & $\mathrm{~g} \mathrm{~g}_{\text {biomass }}{ }^{-1}$ & & \\
\hline $\begin{array}{l}\text { Anabaena sp. } \\
\text { ATCC } 33047\end{array}$ & Flask (1 L) & $\begin{array}{c}\mathrm{NaHCO}, \mathrm{KCl}, \mathrm{K}_{2} \mathrm{HPO}_{4} \\
\mathrm{MgSO}_{4}, \mathrm{CaCl}_{2}, \mathrm{NaCl}\end{array}$ & 17.2 & - & $460 \mu \mathrm{E} \mathrm{m}^{-2} \mathrm{~s}^{-1} ; 40^{\circ} \mathrm{C}$ & [25] \\
\hline $\begin{array}{c}\text { Botryococcus braunii } \\
\text { UC } 58\end{array}$ & Cylindrical flask & $\begin{array}{c}\mathrm{Chu} 13 ; \mathrm{KNO}_{3} ; \\
\mathrm{CO}\left(\mathrm{NH}_{2}\right)_{2} ;\left(\mathrm{NH}_{4}\right)_{2} \mathrm{CO}_{3} ; \\
1 \% \mathrm{CO}_{2}, 31 \mathrm{~d}\end{array}$ & 2.4 & 2.2 & $250 \mu \mathrm{E} \mathrm{m}^{-2} \mathrm{~s}^{-1} ; 25^{\circ} \mathrm{C}$ & [26] \\
\hline Chlamydomonas reinhardtii & Flask (1 L) & $\begin{array}{c}\mathrm{CaCl}_{2} ; \mathrm{NaNO}_{3} ; \\
\mathrm{K}_{2} \mathrm{HPO}_{4} ; \mathrm{MgSO}_{4} 9 \mathrm{~d}\end{array}$ & 0.63 & - & $20 \mu \mathrm{mol} \mathrm{m}{ }^{-2} \mathrm{~s}^{-1}$ & [27] \\
\hline Chlorella sp. & Flask (1 L) & $\begin{array}{c}\mathrm{CH}_{3} \mathrm{OH} ; \mathrm{C}_{2} \mathrm{H}_{5} \mathrm{OH} ; \\
\mathrm{C}_{12} \mathrm{H}_{22} \mathrm{O}_{11} ; \mathrm{C}_{6} \mathrm{H}_{12} \mathrm{O}_{6} ; \\
\mathrm{CH}_{3} \mathrm{COONa} ; \mathrm{C}_{2} \mathrm{H}_{5} \mathrm{NO}_{2} ; \\
\mathrm{NaHCO}_{3} ; \text { two salinity } \\
\text { conditions (fresh water } \\
\text { and sea water) }\end{array}$ & 0.03 & - & $\begin{array}{c}\text { Intense lighting } \\
\text { (studied factor); } 20^{\circ} \mathrm{C}\end{array}$ & [22] \\
\hline Chlorella zofingiensis & Flask & $\begin{array}{l}\text { Mixotrophic cultivation } \\
\text { (BG-11;5.0 } \mathrm{g} \mathrm{L}^{-1} \\
\text { glucose); } 5 \mathrm{~d}\end{array}$ & 0.21 & 0.09 & $40 \mu \mathrm{E} \mathrm{m}^{-2} \mathrm{~s}^{-1} ; 25^{\circ} \mathrm{C}$ & [28] \\
\hline Nostoc sp. & Flask $(0.25 \mathrm{~L})$ & BG-11 & 0.17 & 0.21 & $80 \mu \mathrm{E} \mathrm{m}^{-2} \mathrm{~s}^{-1} ; 25^{\circ} \mathrm{C}$ & [29] \\
\hline Nostoc flageliforme & Flask (500 mL) & BG-11 & 0.22 & - & $60 \mu \mathrm{mol} \mathrm{m}{ }^{-2} \mathrm{~s}^{-1} ; 25^{\circ} \mathrm{C}$ & [30] \\
\hline Rhodella violacea & $\begin{array}{c}\text { Vertical } \\
\text { photobioreactor with } \\
\text { flask }(700 \mathrm{~mL})\end{array}$ & $\begin{array}{c}\mathrm{F} / 2 \text { medium } \\
\text { supplemented with } \\
\mathrm{NaNO}_{3} \text { and } \mathrm{NaH}_{2} \mathrm{PO}_{4}\end{array}$ & 0.59 & - & $420 \mu \mathrm{E} \mathrm{m}^{-2} \mathrm{~s}^{-1} ; 24^{\circ} \mathrm{C}$ & [31] \\
\hline Spirulina sp. & $\begin{array}{c}\text { Flask (5 L) and flask } \\
\qquad(0.25 \mathrm{~L})\end{array}$ & $\begin{array}{l}\text { Zarrouk medium; } \\
1 \mathrm{~g} \mathrm{~L}^{-1} \mathrm{NaCl}, 5 \mathrm{~d} \\
40 \mathrm{~g} \mathrm{~L}^{-1} \mathrm{NaCl} ; 3 \mathrm{~d}\end{array}$ & - & 1.0 & $\begin{array}{c}80 \mu \mathrm{mol} \mathrm{m}{ }^{-2} \mathrm{~s}^{-1} \\
10 \mu \mathrm{mol} \mathrm{m}{ }^{-2} \mathrm{~s}^{-1} ; 30^{\circ} \mathrm{C}\end{array}$ & [32] \\
\hline
\end{tabular}


In the cultivation of Cyanothece sp. CCY 0110, the presence of sodium nitrate $\left(\mathrm{NaNO}_{3}\right)$ significantly improved the production of released polysaccharide $\left(1.8 \mathrm{~g} \mathrm{~L}^{-1}\right)$ compared to a cultivation condition without $\mathrm{NaNO}_{3}$ [33]. In another study, Nostoc sp. BTA97 and Anabaena sp. BTA990 produced 1.58 and $1.29 \mathrm{mg} \mathrm{mL}^{-1}$ of exopolysaccharides, respectively, from the absence of a combined nitrogen source [19]. Although $\mathrm{NaNO}_{3}$ is the most common nitrogen source used by microalgae [9], $\mathrm{KNO}_{3}$ is effective for exopolysaccharides' accumulation [34,35]. Han et al. [36] evaluated four nitrogen sources (urea, $\mathrm{NaNO}_{3}, \mathrm{NH}_{4} \mathrm{Cl}$, and arginine) in the Nostoc flagelliform culture. Urea promoted $66 \%$ of biomass production and $217.3 \%$ of exopolysaccharide content.

The nitrogen/phosphorus $(\mathrm{N} / \mathrm{P})$ ratio has been reported to influence the production of exopolysaccharides by microalgae [31,37]. Soanen et al. [38] observed that using an N/P ratio of 3.97, the exopolysaccharide productivity obtained from the microalgae Porphyridium cruentum was $0.0622 \mathrm{mg} \times 10^{-6}$ cells. The authors also observed that increasing the N/P ratio reduced biomolecule accumulation $\left(0.0503 \mathrm{mg} \times 10^{-6}\right.$ cells $)$.

Increased salinity causes stress on microalgal cells due to excess sodium and chloride ions [22]. Studies show that this stress can be beneficial for polysaccharide production. The salt stress generation by sodium chloride $\left(\mathrm{NaCl} 0.3-0.7 \mathrm{~mol} \mathrm{~L}^{-1}\right)$ increased the production of exopolysaccharides by approximately $63 \%$ in Microcoleus vagiantus, which proves to be a protective cellular response [39]. The production of exopolysaccharides by Cyanothece sp. increased when the microalga was cultivated with high salinity $\left(70 \mathrm{~g} \mathrm{~L}^{-1}\right)$ [40]. In another study, the increase in the salinity of freshwater $(0.1 \%)$ to seawater $(3.5 \%)$ induced the production of exopolysaccharides for the Chlorella sp. from 3 to 30 times [22].

\subsection{Temperature and Light Intensity}

The continuous exposure to high light intensity influences the exopolysaccharides synthesis by microalgae and cyanobacteria. The ideal cultivation for exopolysaccharide production by Cyanothece sp. 113 resulted from continuous illumination of $86.0 \mu \mathrm{E} \mathrm{m}^{-2} \mathrm{~s}^{-1}$ [40]. Compared to the control condition (white light), the red light provides a higher accumulation of exopolysaccharides and capsular polysaccharides $\left(44.4\right.$ and $261.3 \mathrm{mg} \mathrm{g}^{-1}$, respectively) in Nostoc flagelliform [36]. Ge et al. [29] observed that the highest light intensity $\left(80 \mu \mathrm{E} \mathrm{m}^{-2} \mathrm{~s}^{-1}\right)$ favored the exopolysaccharide and capsular polysaccharide contents in Nostoc sp. (206.2 and $71.9 \mathrm{mg} \mathrm{g}^{-1}$, respectively). With $40 \mu \mathrm{E} \mathrm{m}^{-2} \mathrm{~s}^{-1}$, the microalga accumulated $155.4 \mathrm{mg} \mathrm{g}^{-1}$ of exopolysaccharides and $57.7 \mathrm{mg} \mathrm{g}^{-1}$ of capsular polysaccharides.

The optimal temperature for exopolysaccharide growth depends on the microalgal strain cultivated [41]. The exopolysaccharides production in Anabaena sp. $\left(3 \mathrm{~g} \mathrm{~L}^{-1}\right)$ increased approximately 4-5 times by changing the culture temperature from 30-35 to $40-45^{\circ} \mathrm{C}$ [25]. Yu et al. [30] observed that for Nostoc flageliforme cultivated in BG-11 medium, exopolysaccharide accumulation was favored at $25^{\circ} \mathrm{C}$, in which production reached a yield of $228.56 \mathrm{mg} \mathrm{L}^{-1}$. In another study, a production of $9.5 \mathrm{~g} \mathrm{~L}^{-1}$ of exopolysaccharides was found from Spirulina sp. LEB 18 cultivated in a pilot-scale and raceway reactor. Optimal conditions of temperature $\left(33-35^{\circ} \mathrm{C}\right)$ and light intensity favored high exopolysaccharide productivity [42]. When cultivated in an Erlenmeyer flask, the same cyanobacterium presented an exopolysaccharide yield of $0.21 \mathrm{~g} \mathrm{~L}^{-1}$ [43].

\section{Extraction and Fractionation/Purification}

After carrying out the microalgae cultivation under conditions that maximize the polysaccharide content, it is interesting that the extraction process used is efficient, economical, and environmentally correct. The choice of suitable extraction and purification technologies is essential to make it possible to isolate polysaccharides with high yield and purity $[9,10]$ to direct the commercial application of these compounds [11].

Centrifugation or microfiltration are commonly used to separate microalgal cells from polysaccharides [10]. Hence, polysaccharides are precipitated with methanol, ethanol, isopropanol, or acetone [9]. Concentration under vacuum at low temperatures $\left(50-60{ }^{\circ} \mathrm{C}\right)$ can be used to minimize the use of alcohol or acetone [11]. Exopolysaccharides can remain 
attached to cells during extraction $[9,44]$. Thus, physical processes such as sonication, microwave-assisted extraction, and ultrasound-assisted extraction treatments have been applied. Chemical and/or ionic methods, such as the use of formaldehyde, glutaraldehyde, ethylenediaminetetraacetic acid, sodium hydroxide, hot water, and ionic resin, can also be used to extract cell-bound polysaccharides [9,10,44].

Chromatographic techniques, such as ion-exchange chromatography, size exclusion chromatography, and affinity chromatography, are widely used to purify and fractionate microalgal polysaccharides [20,45-47]. Ion exchange chromatography uses the difference between the charge properties of molecules to promote separation. By manipulating the $\mathrm{pH}$, it is possible to change the net surface charge of charged biomolecules to achieve higher selectivity [48]. Size exclusion chromatography can be used to separate microalgal polysaccharides with different molecular weights or molecular sizes [49]. Gel permeation chromatography is a widely used size exclusion chromatography for separating macromolecules. For microalgae, this technique has been applied to characterize polysaccharides [48]. In affinity chromatography, the target molecule charged by the mobile phase binds to the immobilized ligand on the stationary phase by affinity. The recovery of these molecules is carried out by other washing and elution steps [50]. The choice of polysaccharide purification techniques depends on the requirement of their purity and type of application. Chromatographic techniques, for example, are interesting for the pharmaceutical sector since they provide a high purity of polysaccharides [49].

Recently, tangential microfiltration or ultrafiltration and dialysis have been investigated as alternative procedures for polysaccharide purification [11]. The application of these types of technologies is advantageous when the polysaccharide is accumulated by marine microalgae since alcoholic precipitation can result in co-precipitation of the polysaccharides with constituent salts in the culture medium [10]. After extraction and purification, the polysaccharides are finally lyophilized or dried under a vacuum [11]. Thus, the choice of reagents and the proportion of volume used, as well as the technologies applied for the extraction and purification of polysaccharides (Table 2) may vary according to the microalgal strain, type of polysaccharide application, and/or the purpose of the study.

Table 2. Process parameters for isolation of polysaccharides from microalgae/cyanobacteria.

\begin{tabular}{|c|c|c|c|c|}
\hline Microalga/Cyanobacteria & $\begin{array}{c}\text { Biomass Pretreatment for } \\
\text { Polysaccharide } \\
\text { Extraction }\end{array}$ & Main Isolation Processes & $\begin{array}{l}\text { Polysaccharides } \\
\text { Contents and/or } \\
\text { Molecular Weight }\end{array}$ & Reference \\
\hline Spirulina platensis & $\begin{array}{l}\text { Ultrasonic treatment; } \mathrm{pH} \\
\text { from } 11 \text { to } 7 .\end{array}$ & 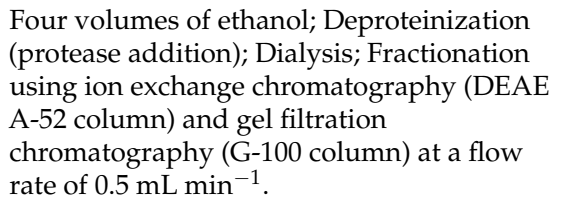 & $\begin{array}{c}16.7 \% \\
(1996 \mathrm{kDa})\end{array}$ & {$[51]$} \\
\hline Chlorella pyrenoidosa & $\begin{array}{l}\text { Ultrasound assisted } \\
\text { extraction. }\end{array}$ & $\begin{array}{l}\text { Four volumes of ethanol; Deproteinization } \\
\text { (protease addition); Dialysis; Fractionation } \\
\text { using ion exchange chromatography } \\
\text { (DEAE- } 52 \text { column) and gel filtration } \\
\text { chromatography (G-100 column) at a flow } \\
\text { rate of } 0.42 \mathrm{~mL} \mathrm{~min}{ }^{-1} \text {. }\end{array}$ & $5630 \mathrm{kDa}$ & [52] \\
\hline Chlorella vulgaris & $\begin{array}{l}\text { Hydration in sodium } \\
\text { acetate buffer }+ \text { cysteine }+ \\
\text { EDTA (pH 5.0) and } \\
\text { incubation with crude } \\
\text { papain at } 60^{\circ} \mathrm{C} \text {. }\end{array}$ & $\begin{array}{l}\text { Two volumes of ethanol; Fractionation using } \\
\text { DEAE-Sephaore ion exchange column eluted } \\
\text { with } \mathrm{NaCl} \text { solutions at a rate of } 1 \mathrm{~mL} \mathrm{~min}{ }^{-1} \text {. }\end{array}$ & $15.0 \%$ & {$[53]$} \\
\hline $\begin{array}{c}\text { Phaeodactylum tricornutum, } \\
\text { Porphyridium sp., } \\
\text { Dunaliella salina and } \\
\text { Arthrospira platensis }\end{array}$ & $\begin{array}{l}\text { Dry biomass suspended in } \\
\text { distilled water and } \\
\text { incubated at } 90^{\circ} \mathrm{C} \text { under } \\
\text { agitation. }\end{array}$ & $\begin{array}{l}\text { Two volumes of ethanol; Recovery by } \\
\text { centrifugation + washing (three times with } \\
\text { absolute ethanol). }\end{array}$ & $\begin{array}{l}\text { 12.7\% (Phaeodactylum } \\
\text { tricornutum) } \\
5.5 \% \text { (Porphyridium sp.) } \\
\text { 4.1\% (Dunaliella salina) } \\
\text { 2.5\% (Arthrospaira } \\
\text { platensis) }\end{array}$ & {$[54]$} \\
\hline
\end{tabular}


Table 2. Cont.

\begin{tabular}{|c|c|c|c|c|}
\hline Microalga/Cyanobacteria & $\begin{array}{c}\text { Biomass Pretreatment for } \\
\text { Polysaccharide } \\
\text { Extraction }\end{array}$ & Main Isolation Processes & $\begin{array}{l}\text { Polysaccharides } \\
\text { Contents and/or } \\
\text { Molecular Weight }\end{array}$ & Reference \\
\hline Neochloris oleoabundans & $\begin{array}{l}\text { Heating }\left(80^{\circ} \mathrm{C}\right) \text { and } \\
\text { concentration of the } \\
\text { cell-free medium to a } \\
\text { quarter of its original } \\
\text { volume under reduced } \\
\text { pressure and } 60^{\circ} \mathrm{C} \text {. }\end{array}$ & $\begin{array}{l}\text { Addition of } 95 \% \text { ethanol until ethanol content } \\
\text { reaches } 30 \% \text {; Deproteinization with Sevag } \\
\text { agent (n-butyl alcohol: chloroform: }=1: 4) ; \\
\text { Dialysis in cellulose membrane tube and } \\
\text { concentration under reduced pressure; } \\
\text { Fractionation over a DEAE-Sephacel column } \\
\text { and gel filtration chromatography on } \\
\text { Sephadex G200 eluted with } 0.1 \mathrm{M} \mathrm{NaCl} \text {. }\end{array}$ & $\begin{array}{l}1 \mathrm{~g} \mathrm{~L}^{-1} \text { (crude } \\
\text { polysaccharide); } \\
0.73 \mathrm{~g} \mathrm{~g}^{-1} \text { (after } \\
\text { purification, } 517 \mathrm{kDa}) \text {. }\end{array}$ & {$[20]$} \\
\hline $\begin{array}{c}\text { Haematococcus } \\
\text { Pluvialis }\end{array}$ & $\begin{array}{l}\text { Ultrasound assisted } \\
\text { extraction }\end{array}$ & $\begin{array}{l}\text { Anhydrous ethanol precipitation; } \\
\text { Deproteinization with Sevag agent } \\
\text { (n-butanol: chloroform }=1: 5) \text {; Fractionation } \\
\text { using a DEAEcellulose- } 52 \text { chromatography } \\
\text { column }\left(2 \mathrm{~mL} \mathrm{~min}{ }^{-1}\right) \text {; Sephacryl S- } 400 \text { gel } \\
\text { permeation chromatography }\left(0.3 \mathrm{~mL} \mathrm{~min}{ }^{-1}\right) \text {. }\end{array}$ & $23413 \mathrm{kDa}$ & {$[45]$} \\
\hline
\end{tabular}

\section{Characterization of Microalgal Polysaccharides}

\subsection{Chemical Composition}

Polysaccharides are polymeric carbohydrate macromolecules with complex structures in terms of monosaccharide composition [55,56]. The chemical composition of polysaccharides, including exopolysaccharides in microalgae and cyanobacteria, depends on taxonomy, culture parameters such as temperature, light intensity, presence of metal ions, nutrient concentration, as well as the culture age. According to the chemical composition, exopolysaccharides can be divided into homopolysaccharides (composed of a type of monosaccharide) and heteropolysaccharides (comprising two or more types of monomeric units) [57].

Microalgal polysaccharides are heteropolymers composed mainly of galactose, xylose, and glucose in different proportions, linked by glycosidic bonds [17]. Other sugars, such as rhamnose, fucose, arabinose, mannose, orthomethyl sugar, and acid residues of glucuronic acid and galacturonic acid can also be constituents of polysaccharides from microalgae and cyanobacteria [57]. Glucose is the most commonly found sugar. Fructose is not generally found in microalgal exopolysaccharides. However, it is often constituted in exopolysaccharides produced by cyanobacteria [56] (Table 3). Guo et al. [7] described heteropolysaccharides from Chlorella pyrenoidosa composed of rhamnose, glucosamine, glucuronic acid, glucose, mannose, fucose, galactose, and xylose. In the same study, Spirulina platensis presented predominantly rhamnose and glucose monosaccharides, in addition to the presence of glucuronic acid, mannose, glucosamine, fucose, and xylose. Jesus et al. [18] reported glucose as the predominant monosaccharide in the composition of extracellular polymeric substances from Spirulina.

Table 3. Chemical composition of exopolysaccharides from microalgae and cyanobacteria.

\begin{tabular}{|c|c|c|c|c|c|c|}
\hline Microorganism & Sugar Composition & $\begin{array}{l}\text { Uronic } \\
\text { Acids }\end{array}$ & Sulphates & $\begin{array}{l}\text { Methylated } \\
\text { Sugars }\end{array}$ & $\begin{array}{l}\text { Amino } \\
\text { Acids }\end{array}$ & Reference \\
\hline Anabaena sp. & Glucose ${ }^{*}$, xylose $*$, rhamnose & + & - & - & - & [46] \\
\hline $\begin{array}{l}\text { Arthrospira } \\
\text { platensis }\end{array}$ & $\begin{array}{l}\text { Fructose, fucose, galactose, glucose }{ }^{*} \\
\text { mannose, rhamnose, ribose, xylose }\end{array}$ & + & - & - & - & [58] \\
\hline $\begin{array}{l}\text { Arthrospira } \\
\text { platensis }\end{array}$ & $\begin{array}{l}\text { Glucose }{ }^{*} \text {, rhamnose, arabinose, fucose, } \\
\text { mannose, galactose, xylose }\end{array}$ & + & - & - & - & [59] \\
\hline $\begin{array}{c}\text { Chlorella } \\
\text { pyrenoidosa }\end{array}$ & $\begin{array}{c}\text { Mannose, rhamnose, glucose, fucose, xylose, } \\
\text { arabinose }\end{array}$ & + & - & - & - & [52] \\
\hline $\begin{array}{l}\text { Chlorella } \\
\text { vulgaris }\end{array}$ & $\begin{array}{l}\text { Fructose, glucose *, maltose, lactose, } \\
\text { rhamnose, arabinose }\end{array}$ & + & + & - & + & {$[60]$} \\
\hline
\end{tabular}


Table 3. Cont.

\begin{tabular}{|c|c|c|c|c|c|c|}
\hline Microorganism & Sugar Composition & $\begin{array}{l}\text { Uronic } \\
\text { Acids }\end{array}$ & Sulphates & $\begin{array}{l}\text { Methylated } \\
\text { Sugars }\end{array}$ & $\begin{array}{l}\text { Amino } \\
\text { Acids }\end{array}$ & Reference \\
\hline Dixoniella grisea & Xylose ${ }^{*}$, rhamnose & + & + & + & - & [8] \\
\hline Gloeocapsa sp. & $\begin{array}{l}\text { Fucose, rhamnose, arabinose } * \text {, galactose, } \\
\text { glucose } * \text { mannose, fructose, xylose }{ }^{*} \text {, ribose }\end{array}$ & + & - & - & - & {$[61]$} \\
\hline Graesiella sp. & $\begin{array}{l}\text { Glucose, galactose, mannose, fucose } \\
\text { rhamnose, xylose, arabinose, ribose }\end{array}$ & + & + & - & + & {$[62]$} \\
\hline $\begin{array}{l}\text { Neochloris } \\
\text { oleoabundans }\end{array}$ & $\begin{array}{l}\text { Glucose *, mannose *, galactose }{ }^{*} \text {, xylose, } \\
\text { ribose, arabinose, rhamnose }\end{array}$ & + & - & - & + & [20] \\
\hline Nostoc carneum & Xylose ${ }^{*}$,glucose & + & + & - & - & [63] \\
\hline $\begin{array}{l}\text { Porphyridium } \\
\text { aerugineum }\end{array}$ & Xylose ${ }^{*}$, glucose, galactose & + & + & + & - & [8] \\
\hline $\begin{array}{l}\text { Spirulina sp. } \\
\text { LEB } 18\end{array}$ & Glucose, fructose, galactose & + & - & - & + & [18] \\
\hline
\end{tabular}

+ detected, - absent $/$ not detected, ${ }^{*}$ dominant sugar (s).

Uronic acids, pyruvates, and acyl groups of carbohydrates or carboxylic groups of amino acids in the protein portion contribute to the anionic nature of exopolysaccharides $[18,64]$. These characteristics confer affinity for positively charged ions (mainly metallic ions). With this, microalgae exopolysaccharides present high potentiality for bioremediation use [57]. On the other hand, acetyl groups linked to ester, peptide fractions, and fucose and rhamnose are responsible for the hydrophobic nature of some exopolysaccharides. Due to these hydrophobic groups, these polysaccharides have interesting emulsifying properties for various industrial applications $[57,65]$.

\subsection{Functional Characteristics}

Polysaccharides are natural macromolecules that participate in several biological processes, such as cell adhesion, cell-to-cell communication and immune response [10,66]. Moreover, these bioactive compounds have antioxidant, immunomodulatory, anticancer, antimicrobial, anti-inflammatory, and antiviral activities [10,67]. Polysaccharides from Chlorella and Spirulina, for example, have been reported as anti-obesity agents [7]. Polysaccharides produced by Chlorella vulgaris have also been shown to prevent chronic airway inflammation $[60,68]$. Thus, due to these potentialities, there is interest in the use of microalgal polysaccharides for applications in nutraceuticals and drugs [67].

The functional properties of polysaccharides differ according to the composition of monosaccharides, molecular weight, sulfate and uronic acid content, type of bonds, and distribution in the molecule. Moreover, chain size and conformation in space, presence of other chemical groups (amino acids, proteins, or nucleic acids), and solvents used during the extraction of these compounds are factors that influence their properties $[17,64,67,69]$. Tannin-Spitz et al. [70] related the antioxidant potential of the exopolysaccharide from Porphyridium cruentum with its sulfate content (4.5\%) and/or the presence of glycoprotein $(66 \mathrm{kDa})$. Furthermore, the antioxidant property of polysaccharides can be inversely related to their molecular weight [10]. In a study by Sun et al. [71], it was found that the $6.5 \mathrm{kDa}$ fragment had higher radical scavenging activity than the 256 and $60.6 \mathrm{kDa}$ fragments.

Immunomodulatory effects were also related to the molecular weight of the polysaccharide. Low molecular weight exopolysaccharides from Porphyridium cruentum had better immunomodulatory effects. This same study proved that at high concentrations of the exopolysaccharide ( $\left.200 \mathrm{mg} \mathrm{kg}^{-1} \mathrm{~d}^{-1}\right)$, tumor inhibition was $53.3 \%$ [72]. Other antiproliferative effects were observed by polysaccharides from Graesiella sp. [62], Tribonema sp. [73], and Phaeodactylum tricornutum [74] against HepG2 cell lines (liver cancer).

In a study developed by Liberman et al. [75], it was found that the polysaccharide from Porphyridium sp. showed antibacterial activity against Escherichia coli (72\%) and Bacillus 
subtilis ( $35 \%$ reduction). The authors related the antibacterial capacity of polysaccharides to the different compositions and structures of bacterial cell walls. Liberman et al. [75] also evaluated the synergy between the polysaccharide and $\mathrm{Zn}^{2+}$ bioactivities and found that the biomaterial presented a promising potential for the development of new pharmaceutical and cosmetic products.

Regarding the antiviral potential of microalgae polysaccharides, strains with a high degree of sulphation and uranic acid content stand out. These acidic compounds and the half-ester sulfate groups and carboxyl groups contribute to the anionic properties of exopolysaccharides and consequently act as protective agents against viruses [64].

\subsection{Rheological Properties}

Polysaccharides secreted by microalgal cells increase the viscosity of the culture medium. The culture medium generally exhibits non-Newtonian rheological behavior [76]. Even at low concentrations, polysaccharides tend to form highly viscous solutions. This fact can be related to the formation of hydrogen bonds due to hydroxyl or amino groups in the chain structure [8]. Thus, rheological properties can be used as a strategy to assess the polysaccharide content in microalgae [20].

The chemical composition of polysaccharides also interferes with the rheological properties of the solutions. Libermann et al. [8] compared the rheological characteristics of sulfated polysaccharide solutions from Dixoniella grisea and Porphyridium aerugineum with the polysaccharide from Porphyridium sp. According to the authors, differences in the rheology of polysaccharides are related to their sugar composition and sulfate contents. The content of charged groups (sulfate and glucuronic acid) in the polysaccharide of Porphyridium sp. $(\sim 21 \%)$ was higher than that found in the polysaccharides Dixoniella grisea and Porphyridium aerugineum ( 13 and $\sim 9 \%$, respectively). The greater amount of charged groups contributes to greater repulsion between the chains, resulting in lower viscosity.

The rheological characteristics contribute to expand the use of polysaccharides as thickeners, gelling agents, and preservatives in the food and pharmaceutical industries $[46,57]$. The addition of ions does not significantly interfere in the rheology of polysaccharide solutions. Thus, the addition of the salts on microalgal polysaccharides has shown that these components are stable over a wide range of ionic strengths. This information can be considered relevant for the food industry since $\mathrm{CaCl}_{2}$ and $\mathrm{NaCl}$ are commonly used in food formulations [8,77]. Furthermore, Prybylski et al. [10] reported that viscosity may be related to the functional activities of polysaccharides. Anti-inflammatory and hypocholesterolemic properties were associated with the high viscosity of the polysaccharide from Porphyridium cruentum.

\section{Applications of Polysaccharides}

Microalgae can produce a range of polysaccharides with interesting physicochemical properties and antioxidant potential. Wan et al. [4] purified polysaccharides from microalga Chlorella pyrenoidosa and evaluated their effect on increasing the lifetime of Caenorhabditis elegans. The authors observed a decrease in reactive oxygen species (ROS) and lipid peroxidation, in addition to an increase in the activity of the antioxidant enzyme (superoxide dismutase) in the model organism. Thus, the authors concluded that these polysaccharides could potentially regulate aging and oxidative diseases. In another study, Li et al. [6] demonstrated that polysaccharides from Nostoc (Nostoglycan) were able to reduce reactive oxygen species, inhibit lipid peroxidation, and suppress tumor cell proliferation.

Moreover, polysaccharides from microalgae and cyanobacteria have been studied for applications as plant biostimulants (Table 4) due to characteristics such as bioactivity and permeability capacity, besides effects on plant key mechanisms such as photosynthesis [17], in addition to resulting in increases in its proteins and carotenoids [78]. Thus, polysaccharides could be applied to reduce the use of pesticides and contribute to the promotion of sustainable agriculture [54]. According to Chanda et al. [17], polysaccharides 
from microalgae can stimulate plant growth and resistance by different mechanisms, such as increasing nutrient access through the roots and photosynthesis by the shoot.

Table 4. Potential application of polysaccharides from different strains of microalgae and cyanobacteria.

\begin{tabular}{|c|c|c|}
\hline Strains & Potential application & Reference \\
\hline $\begin{array}{l}\text { Desmodesmus sp., P. tricornutum, Porphorydium } \\
\text { sp., Arthrospira platensis, and Dunaliella salina }\end{array}$ & $\begin{array}{l}\text { Plant (tomato) } \\
\text { resistance inducer }\end{array}$ & {$[54]$} \\
\hline $\begin{array}{c}\text { Arthrospira platensis, Dunaliella salina, and } \\
\text { Porphorydium sp. }\end{array}$ & $\begin{array}{l}\text { Plant (tomato) } \\
\text { bio-stimulant }\end{array}$ & {$[78]$} \\
\hline Chlorella vulgaris & $\begin{array}{c}\text { Plant (wheat and } \\
\text { French bean) } \\
\text { bio-stimulant }\end{array}$ & {$[60]$} \\
\hline Nostoc sphaeroides & $\begin{array}{l}\text { Food and health } \\
\text { industries }\end{array}$ & {$[6]$} \\
\hline Spirulina platensis & Functional food & [51] \\
\hline Porphyridium sp. & $\begin{array}{l}\text { Thickening/lubrication } \\
\text { agent }\end{array}$ & {$[8]$} \\
\hline
\end{tabular}

Recently, due to the great worldwide concern, researchers have been looking for environmentally friendly solutions for the bioremediation of different wastewater contaminants. In this context, Cunha et al. [79] evaluated extracellular polymeric substances from Cyanothece sp. for removing nano and microplastics from water. The authors observed that the biopolymer from the microalga acted as a bioflocculant and aggregated polystyrene plastic particles. However, exposure to plastic contaminants resulted in a significant reduction in microalgal growth.

Arad and Levy-Ontman have reported the capacity of red-microalgal polysaccharides to benefit human health and also highlighted its applications for medicinal and cosmetic areas [80]. In the commercial stage, exopolysaccharides from Porphyridium cruentum are already used to develop cosmetic active ingredients for skin hydration [12]. Some companies isolate polysaccharides from Porphyridium cruentum. EPS Revive, a sulfated polysaccharide produced by the Yemoja company, is already marketed to the cosmetics industry. The company has several applications for the product, such as anti-aging, anti-inflammatory, and rejuvenating properties. The company AlgaTech cultivates Porphyridium cruentum and mentions that the microalgae biomass can contain up to $40 \%$ polysaccharides with great potential to protect the cell against environmental stress and provide carbon skeletons during starvation periods. According to Pierre et al. [81], despite the range of studies on the analytical stage about EPS from microalgae and the various existing suggestions for its uses in a range of areas, its application and valorization are generally limited to high priced products such as food and nutraceuticals, cosmetics, and pharmaceutical fields due to the high production costs.

\section{Challenges and Future Perspectives}

Despite a range of benefits, the production of exopolysaccharides from microalgae faces obstacles such as achieving a high microalgal growth rate and high exopolysaccharide production simultaneously during cultivation. Some issues related to the production of polysaccharides can be addressed by optimizing cultivation variables, such as shear stress, temperature, and light quality [11].

Another challenge is to cultivate microalgae with high salinity, as these salts can make the precipitation step of exopolysaccharides difficult. Thus, several research suggests the application of processes such as dialysis or tangential ultrafiltration to separate the salts from exopolysaccharides [5,9]. Besides helping to desalt the exopolysaccharides, this step can add value to the process, as high-value compounds such as pigments can be obtained 
simultaneously [5]. However, during ultrafiltration, the process efficiency may be reduced, depending on the viscosity of the microalgal exopolysaccharides [9]. Freshwater strains application on EPS production could also be an alternative to avoid the desalting step [81].

The presence of proteins, pigments, and cell wall materials interferes negatively in polysaccharide separation and quantification assays [9]. Furthermore, the cell-bound polysaccharide is another challenge when it comes to the extraction steps [5]. To obtain these compounds, physical methods can also be applied [10].

According to Pierre et al. [81], microalgae produce EPS more slowly than bacteria, presenting higher production costs. Additionally, some processes of the extraction, purification, and quantification of polysaccharides from microalgae have high costs, which limits their application in certain fields. The conventional methods for evaluating polysaccharides from microalgae require high investments (financial and time) [67]. In this context, to assist in routine analyses, Decamp et al. [67] developed a new method to determine the composition of microalgal polysaccharides and facilitate the checking of microalgae cultivation. The new protocol resulted in findings close to those obtained using conventional chromatography, in addition to advantages such as less time and cost requirements. In another study, Li et al. [20] proposed an indirect quantitative method of rapid assessment to determine exopolysaccharides based on their rheological properties in the medium. Thus, it is concluded that the development of affordable and practical methods can be considered an interesting approach to overcome the barriers of the quantification of exopolysaccharides from microalgae.

\section{Conclusions}

Microalgae are promising alternatives for obtaining polysaccharides while contributing to the mitigation of the environmental pollution generated by industrial waste. Microalgal polysaccharides have promising rheological and biological properties for applications in various sectors, especially in the food, pharmaceutical, and cosmetic industries. However, one of the biggest challenges is to optimize the growing conditions and extraction processes to promote higher productivity and polysaccharide yield, respectively. The market share of these biocompounds with hydrocolloid characteristics is still limited, as production costs are not competitive with those produced from other well-established raw materials, such as macroalgae and plants. Furthermore, a microalgal biorefinery approach can be a strategy to reduce costs and increase competitiveness, using biomass for the production of polysaccharides and other compounds of commercial interest.

Author Contributions: Writing—original draft preparation, B.F.L., A.G.P.A., and J.B.M.; writingreview and editing, B.F.L., A.G.P.A., J.B.M., and M.G.d.M.; supervision project administration, J.A.V.C. and M.G.d.M. All authors have read and agreed to the published version of the manuscript.

Funding: This research received no external funding.

Institutional Review Board Statement: Not applicable.

Informed Consent Statement: Not applicable.

Data Availability Statement: Not applicable.

Acknowledgments: This study was financed in part by the Coordenação de Aperfeiçoamento de Pessoal de Nível Superior-Brasil (CAPES)-Finance Code 001. This research was developed within the scope of the Capes-PrInt Program (Process \# 88887.310848/2018-00).

Conflicts of Interest: The authors declare no conflict of interest.

\section{References}

1. Costa, J.A.V.; Freitas, B.C.B.; Moraes, L.; Zaparoli, M.; Morais, M.G. Progress in the physicochemical treatment of microalgae biomass for value-added product recovery. Bioresour. Technol. 2020, 301, 122727. [CrossRef] [PubMed]

2. Chen, Y.-X.; Liu, X.-Y.; Xiao, Z.; Huang, Y.-F.; Liu, B. Antioxidant activities of polysaccharides obtained from Chlorella pyrenoidosa via different ethanol concentrations. Int. J. Biol. Macromol 2016, 91, 505-509. [CrossRef] [PubMed] 
3. Phélippé, M.; Gonçalves, O.; Thouand, G.; Cogne, G.; Laroche, C. Characterization of the polysaccharides chemical diversity of the cyanobacteria Arthrospira Platensis. Algal Res. 2019, 38, 101426. [CrossRef]

4. Wan, X.; Li, X.; Liu, D.; Gao, X.; Chen, Y.; Chen, Z.; Fu, C.; Lin, L.; Liu, B.; Zhao, C. Physicochemical characterization and antioxidant effects of green microalga Chlorella pyrenoidosa polysaccharide by regulation of microRNAs and gut microbiota in Caenorhabditis elegans. Int. J. Biol. Macromol. 2021, 168, 152-162. [CrossRef]

5. Gaignard, C.; Gargouch, N.; Dubessay, P.; Delattre, C.; Pierre, G.; Laroche, C.; Fendri, I.; Abdelkafi, S.; Michaud, P. New horizons in culture and valorization of red microalgae. Biotechnol. Adv. 2019, 37, 193-222. [CrossRef] [PubMed]

6. Li, H.; Su, L.; Chen, S.; Zhao, L.; Wang, H.; Ding, F.; Chen, H.; Shi, R.; Wang, Y.; Huang, Z. Physicochemical characterization and functional analysis of the polysaccharide from the edible microalga Nostoc Sphaeroides. Molecules 2018, 23, 508. [CrossRef] [PubMed]

7. Guo, W.; Zhu, S.; Li, S.; Feng, Y.; Wu, H.; Zeng, M. Microalgae polysaccharides ameliorates obesity in association with modulation of lipid metabolism and gut microbiota in high-fat-diet fed C57BL/6 mice. Int. J. Biol. Macromol. 2021, 182, 1371-1383. [CrossRef]

8. Liberman, G.N.; Ochbaum, G.; Mejubovsky-Mikhelis, M.; Bitton, R.; Arad, S.M. Physico-chemical characteristics of the sulfated polysaccharides of the red microalgae Dixoniella grisea and Porphyridium aerugineum. Int. J. Biol. Macromol. 2020, 145, 1171-1179. [CrossRef]

9. Delattre, C.; Pierre, G.; Laroche, C.; Michaud, P. Production, extraction and characterization of microalgal and cyanobacterial exopolysaccharides. Biotechnol. Adv. 2016, 34, 1159-1179. [CrossRef]

10. Prybylski, N.; Toucheteau, C.; Alaoui, H.E.; Bridiau, N.; Maugard, T.; Abdelkafi, S.; Fendri, I.; Delattre, C.; Dubessay, P.; Pierre, G.; et al. Bioactive polysaccharides from microalgae. In Handbook of Microalgae-Based Processes and Products; Elsevier: Amsterdam, The Netherlands, 2020; pp. 533-571. [CrossRef]

11. Cruz, D.; Vasconcelos, V.; Pierre, G.; Michaud, P.; Delattre, C. Exopolysaccharides from cyanobacteria: Strategies for bioprocess development. Appl. Sci. 2020, 10, 3763. [CrossRef]

12. Givaudan. Hydrintense $\mathrm{TM}_{\mathrm{TM}} \mathrm{A}$ Moisturising Wave for Your Skin. Available online: https://www.givaudan.com/fragrancebeauty / active-beauty/products / hydrintense (accessed on 18 July 2021).

13. Chai, W.S.; Tan, W.G.; Munawaroh, H.S.H.; Gupta, V.K.; Ho, S.-H.; Show, P.L. Multifaceted roles of microalgae in the application of wastewater biotreatment: A review. Environ. Pollut. 2021, 269, 116236. [CrossRef]

14. Morais, M.G.; Morais, E.G.; Cardias, B.B.; Vaz, B.S.; Moreira, J.B.; Mitchell, B.G.; Costa, J.A.V. Microalgae as a source of sustainable biofuels. In Recent Developments in Bioenergy Research; Elsevier: Amsterdam, The Netherlands, 2020; pp. 253-271. [CrossRef]

15. Kumar, M.; Sun, Y.; Rathour, R.; Pandey, A.; Thakur, I.S.; Tsang, D.C.W. Algae as potential feedstock for the production of biofuels and value-added products: Opportunities and challenges. Sci. Total Environ. 2020, 716, 137116. [CrossRef]

16. Lucas, B.F.; Morais, M.G.; Santos, T.D.; Costa, J.A.V. Spirulina for snack enrichment: Nutritional, physical and sensory evaluations. LWT 2018, 90, 270-276. [CrossRef]

17. Chanda, M.-J.; Merghoub, N.; Arroussi, H.E. Microalgae polysaccharides: The new sustainable bioactive products for the development of plant bio-stimulants? World J. Microbiol. Biotechnol. 2019, 35, 177. [CrossRef]

18. Jesus, C.S.; Assis, D.J.; Rodriguez, M.B.; Filho, J.A.M.; Costa, J.A.V.; Ferreira, E.S.; Druzian, J.I. Pilot-scale isolation and characterization of extracellular polymeric substances (EPS) from cell-free medium of Spirulina sp. LEB-18 cultures under outdoor conditions. Int. J. Biol. Macromol. 2019, 124, 1106-1114. [CrossRef] [PubMed]

19. Tiwari, O.N.; Khangembam, R.; Shamjetshabam, M.; Sharma, A.S.; Oinam, G.; Brand, J.J. Characterization and optmization of bioflocculant exopolyssaccharide production by Cyanobacteria Nostoc sp. BTA97 and Anabaena sp. BTA 990 in culture conditions. Appl. Biochem. Biotechnol. 2015, 176, 1950-1963. [CrossRef]

20. Li, Y.; Wang, C.; Liu, H.; Su, J.; Lan, C.Q.; Zhong, M.; Hu, X. Production, isolation and bioactive estimation of extracellular polysaccharides of green microalga Neochloris Oleoabundans. Algal Res. 2020, 48, 101883. [CrossRef]

21. Trabelsi, L.; Ouada, H.B.; Zili, F.; Mazhoud, N.; Ammar, J. Evaluation of Arthrospira platensis extracellular polymeric substances production in photoautotrophic, heterotrophic and mixotrophic conditions. Folia Microbiol. 2013, 58, 39-45. [CrossRef]

22. Vo, H.N.P.; Ngo, H.H.; Guo, W.; Liu, Y.; Chang, S.W.; Nguyen, D.D.; Zhang, X.; Liang, H.; Xue, S. Selective carbon sources and salinities enhance enzymes and extracellular polymeric substances extrusion of Chlorella sp. for potential co-metabolism. Bioresour. Technol. 2020, 303, 122877. [CrossRef] [PubMed]

23. Deamici, K.M.; Morais, M.G.; Santos, L.O.; Muylaert, K.; Gardarin, C.; Costa, J.A.V.; Laroche, C. Static magnetic fields effects on polysaccharides production by different microalgae strains. J. Appl. Sci. 2021, 11, 5299. [CrossRef]

24. González-Fernández, C.; Ballesteros, M. Linking microalgae and cyanobacteria culture conditions and key-enzymes for carbohydrate accumulation. Biotechnol. Adv. 2012, 30, 1655-1661. [CrossRef] [PubMed]

25. Moreno, J.; Vargas, M.A.; Olivares, H.R.; Guerrero, M.G. Exopolysaccharide production by the cyanobacterium Anabaena sp. ATCC 33047 in batch and continuous culture. J. Biotechnol. 1998, 60, 175-182. [CrossRef]

26. Lupi, F.M.; Fernandes, H.M.L.; Tomé, M.M.; Sá-Correia, I.; Novais, J.M. Influence of nitrogen source and photoperiod on exopolysaccharide synthesis by the microalga Botryococcus braunii UC 58. Enzyme Microb. Technol. 1994, 16, 546-550. [CrossRef]

27. Bafana, A. Characterization and optimization of production of exopolysaccharide from Chlamydomonas reinhardtii. Carbohydr. Polym. 2013, 95, 746-752. [CrossRef] 
28. Zhang, J.; Liu, L.; Chen, F. Production and characterization of exopolysaccharides from Chlorella zofingiensis and Chlorella vulgaris with anti-colorectal cancer activity. Int. J. Biol. Macromol. 2019, 134, 976-983. [CrossRef] [PubMed]

29. Ge, H.; Xia, L.; Zhou, X.; Zhang, D.; Hu, C. Effects of Light Intensity on Components and Topographical Structures of Extracellular Polysaccharides from the Cyanobacteria Nostoc sp. J. Microbiol. 2014, 52, 179-183. [CrossRef]

30. Yu, H.; Jia, S.; Dai, Y. Accumulation of exopolysaccharides in liquid suspension culture of Nostoc flagelliforme cells. Biotechnol. Appl. Biochem. 2010, 160, 552-560. [CrossRef] [PubMed]

31. Villay, A.; Laroche, C.; Roriz, D.; El Alaoui, H.; Delbac, F.; Michaud, P. Optimisation of culture parameters for exopolysaccharides production by the microalga Rhodella violacea. Bioresour. Technol. 2013, 146, 732-735. [CrossRef]

32. Chentir, I.; Hamdi, M.; Doumandji, A.; HadjSadok, A.; Ouada, H.B.; Nasri, M.; Jridi, M. Enhancement of extracellular polymeric substances (EPS) production in Spirulina (Arthrospira sp.) by two-step cultivation process and partial characterization of their polysaccharidic moiety. Int. J. Biol. Macromol. 2017, 105, 1412-1420. [CrossRef]

33. Mota, R.; Guimaraes, R.; Büttel, Z.; Rossi, F.; Colica, G.; Silva, C.J.; Santos, C.; Gales, L.; Zille, A.; Philippis, R.; et al. Production and characterization of extracellular carbohydrate polymer from Cyanothece sp. CCY 0110. Carboydr. Polym. 2013, 93, 1408-1415. [CrossRef]

34. Jindal, N.; Singh, D.P.; Khattar, J.I.S. Kinetics and physico-chemical characterization of exopolysaccharides produced by the cyanobacterium Oscillatoria formosa. J. Microbiol. Biotechnol. 2011, 27, 2139-2146. [CrossRef]

35. Khattar, J.I.S.; Singh, D.P.; Jindal, N.; Kaur, N.; Singh, Y.; Rahi, P.; Gulati, A. Isolation and characterization of exopolysaccharides produced by the cyanobacterium Limnothrix redekei PUPCCC 116. Appl. Biochem. Biotechnol. 2010, 162, 1327-1338. [CrossRef]

36. Han, P.-P.; Sun, Y.; Jia, S.-R.; Zhong, C.; Tan, Z.-L. Effects of light wavelengths on extracellular and capsular polysaccharide production by Nostoc flagelliforme. Carbohydr. Polym. 2014, 105, 145-151. [CrossRef]

37. Razaghi, A.; Godhe, A.; Albers, E. Effects of nitrogen on growth and carbohydrate formation in Porphyridium cruentum. Cent. Eur. J. Biol. 2014, 9, 156-162. [CrossRef]

38. Soanen, N.; Silva, E.; Gardarin, C.; Michaud, P.; Laroche, C. Improvement of exopolysaccharide production by Porphyridium marinum. Bioresour. Technol. 2016, 213, 231-238. [CrossRef]

39. Chen, L.-Z.; Li, D.-H.; Song, L.R.; Hu, C.X.; Wang, G.H.; Liu, Y.D. Effects of salt stress on carbohydrate metabolism in desert soil alga Microcoleus vaginatus Gom. J. Integr. Plant. Biol. 2006, 48, 914-919. [CrossRef]

40. Chi, Z.; Su, C.D.; Lu, W.D. A new exopolysaccharide produced by marine Cyanothece sp. 113. Bioresour. Technol. 2007, 98, 1329-1332. [CrossRef] [PubMed]

41. Lakatos, G.E.; Ranglová, K.; Manoel, J.C.; Grivalsky, T.; Kopecky, J.; Masojídek, J. Bioethanol production from microalgae polysaccharides. Folia Microbiol. 2019, 64, 627-644. [CrossRef] [PubMed]

42. Jesus, C.S.; Uebel, L.S.; Costa, S.S.; Miranda, A.L.; Morais, E.G.; Morais, M.G.; Costa, J.A.V.; Nunes, I.L.; Ferreira, E.S.; Druzian, J.I. Outdoor pilot-scale cultivation of Spirulina sp. LEB-18 in different geographic locations for evaluating its growth and chemical composition. Bioresour. Technol. 2018, 256, 86-94. [CrossRef] [PubMed]

43. Trabelsi, L.; Ouada, H.B.; Bacha, H.; Ghoul, M. Combined effect of temperature and light intensity on growth and extracellular polymeric substance production by the cyanobacterium Arthrospira platensis. J. Appl. Phycol. 2009, 21, 405-412. [CrossRef]

44. Gaignard, C.; Laroche, C.; Pierre, G.; Dubessay, P.; Delattre, C.; Gardarin, C.; Gourvil, P.; Probert, I.; Dubuffet, A.; Michaud, P. Screening of marine microalgae: Investigation of new exopolysaccharide producers. Algal Res. 2019, 44, 101711. [CrossRef]

45. Liu, X.; Zhang, M.; Liu, H.; Zhou, A.; Cao, Y.; Liu, X. Preliminary characterization of the structure and immunostimulatory and anti-aging properties of the polysaccharide fraction of Haematococcus pluvialist. RSC Adv. 2018, 8, 9243-9252. [CrossRef]

46. Tiwari, O.N.; Mondal, A.; Bhunia, B.; Bandyopadhyay, T.K.; Jaladi, P.; Oinam, G.; Indrama, T. Purification, characterization and biotechnological potential of new exopolysaccharide polymers produced by cyanobacterium Anabaena sp. CCC 745. Polymer 2019, 178, 121695. [CrossRef]

47. Sushytskyi, L.; Lukáč, P.; Synytsya, A.; Bleha, R.; Rajsiglová, L.; Capek, P.; Pohl, R.; Vannucci, L.; Čopíková, J.; Kaštánek, P. Immunoactive polysaccharides produced by heterotrophic mutant of green microalga Parachlorella kessleri HY1 (Chlorellaceae). Carbohydr. Polym. 2020, 246, 116588. [CrossRef]

48. Corrêa, P.S.; Júnior, W.G.M.; Martins, A.A.; Caetano, N.S.; Mata, T.M. Microalgae biomolecules: Extraction, separation and purification methods. Processes 2021, 9, 10. [CrossRef]

49. Xu, S.-Y.; Huang, X.; Cheong, K.-T. Recent advances in marine algae polysaccharides: Isolation, structure, and activities. Mar. Drugs. 2017, 15, 388. [CrossRef] [PubMed]

50. Urh, M.; Simpson, D.; Zhao, K. Affinity chromatography: General methods. Methods Enzymol. 2009, 463, 417-438. [CrossRef]

51. Chen, Y.; Wan, X.; Wu, D.; Ouyang, Y.; Gao, L.; Chen, Z.; El-Seedi, H.R.; Wang, M.-f.; Chen, X.; Zhao, C. Characterization of the structure and analysis of the anti-oxidant effect of microalga Spirulina platensis polysaccharide on Caenorhabditis elegans mediated by modulating microRNAs and gut microbiota. Int. J. Biol. Macromol. 2020, 163, 2295-2305. [CrossRef] [PubMed]

52. Wan, X.-Z.; Ai, C.; Chen, Y.-H.; Gao, X.-X.; Zhong, R.-T.; Liu, B.; Chen, X.-H.; Zhao, C. Physicochemical characterization of a polysaccharide from green microalga Chlorella pyrenoidosa and its hypolipidemic activity via gut microbiota regulation in rats. J. Agric. Food Chem. 2020, 68, 1186-1197. [CrossRef] [PubMed]

53. Reck, L.; Andrade, F.R.N.; Maia, H.D.; Silva, D.C.; Araújo, A.L.A.C.; Abreu, K.V.; Batista, J.L.; Cavancante, K.M.S.P. Extraction of sulfated polysaccharide from microalgae Chlorella vulgaris produced in effluent generated by pisciculture. Braz. J. Develop. 2020, 6, 64379-64387. [CrossRef] 
54. Rachidi, F.; Benhima, R.; Kasmi, Y.; Sbabou, L.; Arroussi, H.E. Evaluation of microalgae polysaccharides as biostimulants of tomato plant defense using metabolomics and biochemical approaches. Sci. Rep. 2021, 11, 1-16. [CrossRef] [PubMed]

55. Nie, C.; Zhu, P.; Ma, S.; Wang, M.; Hu, Y. Purification, characterization and immunomodulatory activity of polysaccharides from stem lettuce. Carbohydr. Polym. 2018, 188, 236-242. [CrossRef] [PubMed]

56. Rossi, F.; De Philippis, R. Exocellular polysaccharides in microalgae and cyanobacteria: Chemical features, role and enzymes and genes involved in their biosynthesis. In The Physiology of Microalgae, 1st ed.; Borowitzka, M.A., Beardall, J., Raven, J.A., Eds.; Springer: Cham, Switzerland, 2016; pp. 565-590. [CrossRef]

57. Kumar, D.; Kaštánek, P.; Adhikary, S.P. Exopolysaccharides from cyanobacteria and microalgae and their commercial application. Curr. Sci. 2018, 115, 234-241. [CrossRef]

58. Ahmed, M.; Moerdijk-Poortvliet, T.C.W.; Wijnholds, A.; Stal, L.J.; Hasnain, S. Isolation, characterization and localization of extracellular polymeric substances from the cyanobacterium Arthrospira platensis strain MMG-9. Eur. J. Phycol. 2014, 49, 143-150. [CrossRef]

59. Liu, Q.; Yao, C.; Sun, Y.; Chen, W.; Tan, H.; Cao, X.; Xue, S.; Yin, H. Production and structural characterization of a new type of polysaccharide from nitrogen-limited Arthrospira platensis cultivated in outdoor industrial-scale open raceway ponds. Biotechnol. Biofuels 2019, 12, 131. [CrossRef]

60. El-Naggar, N.E.-A.; Hussein, M.H.; Shaaban-Dessuuki, S.A.; Dalal, S.R. Production, extraction and characterization of Chlorella vulgaris soluble polysaccharides and their applications in AgNPs biosynthesis and biostimulation of plant growth. Sci. Rep. 2020, 10, 1-19. [CrossRef] [PubMed]

61. Rossi, F.; Micheletti, E.; Bruno, L.; Adhikary, S.P.; Albertano, P.; De Philippis, R. Characteristics and role of the exocellular polysaccharides produced by fi e cyanobacteria isolated from phototrophic biofilms growing on Indian stone monuments. Biofouling 2012, 28, 215-224. [CrossRef]

62. Trabelsi, L.; Chaieb, O.; Mnari, A.; Abid-Essafi, S.; Aleya, L. Partial characterization and antioxidant and antiproliferative activities of the aqueous extracellular polysaccharides from the thermophilic microalgae Graesiella sp. Complement. Altern. Med. 2016, 12, 210. [CrossRef]

63. Hussein, M.; Abou-ElWafa, G.S.; Shaaban-Dessuuki, S.A.; Hassan, N.I. Characterization and antioxidant activity of exopolysaccharide secreted by Nostoc Carneum. Int. J. Pharm. 2015, 11, 432-439. [CrossRef]

64. De Jesus Raposo, M.F.; de Morais, A.M.M.B.; de Morais, R.M.S.C. Bioactivity and Applications of Polysaccharides from Marine Microalgae. In Polysaccharides; Springer: Cham, Switzerland, 2014; pp. 1-38. [CrossRef]

65. Shepherd, R.; Rockey, J.; Sutherland, I.W.; Roller, S. Novel bioemulsifiers from microorganisms for use in foods. J. Biotechnol. 1995, 40, 207-217. [CrossRef]

66. Dwek, R.A. Glycobiology: Toward understanding the function of sugars. Chem. Rev. 1996, 96, 683-720. [CrossRef] [PubMed]

67. Decamp, A.; Michelo, O.; Rabbat, C.; Laroche, C.; Grizeau, D.; Pruvost, J.; Gonçalves, O. A new, quick, and simple protocol to evaluate microalgae polysaccharide composition. Mar. Drugs 2021, 19, 101. [CrossRef]

68. Barboríková, J.; Šutovská, M.; Kazimierová, I.; Jošková, M.; Fraňová, S.; Kopecký, J.; Capek, P. Extracellular polysaccharide produced by Chlorella vulgaris—Chemical characterization and anti-asthmatic profile. Int. J. Biol. Macromol. 2019, $135,1-11$. [CrossRef] [PubMed]

69. Kashif, A.S.; Hwang, Y.J.; Park, J.K. Potent biomedical applications of isolated polysaccharides from marine microalgae Tetraselmis species. Bioprocess Biosyst. Eng. 2018, 41, 1611-1620. [CrossRef] [PubMed]

70. Tannin-Spitz, T.; Bergman, M.; Grossman, S.; Arad, S. Antioxidant activity of the polysaccharide of the red microalga Porphyridium sp. J. Appl. Phycol. 2005, 17, 215-222. [CrossRef]

71. Sun, L.; Wang, C.; Shi, Q.; Ma, C. Preparation of different molecular weight polysaccharides from Porphyridium cruentum and their antioxidant activities. Int. J. Biol. Macromol. 2009, 45, 42-47. [CrossRef]

72. Sun, L.; Wang, L.; Zhou, Y. Immunomodulation and antitumor activities of different molecular-weight polysaccharides from Porphyridium cruentum. Carbohydr. Polym. 2012, 87, 1206-1210. [CrossRef]

73. Chen, X.; Song, L.; Wang, H.; Liu, S.; Yu, H.; Wang, X.; Li, R.; Liu, T.; Li, P. Partial characterization, the immune modulation and anticancer activities of sulfated polysaccharides from filamentous microalgae Tribonema sp. Molecules 2019, 24, 322. [CrossRef]

74. Yang, S.; Wan, H.; Wang, R.; Hao, D. Sulfated polysaccharides from Phaeodactylum tricornutum: Isolation, structural characteristics, and inhibiting HepG2 growth activity in vitro. PeerJ 2019, 7, e6409. [CrossRef]

75. Liberman, G.N.; Ochbaum, G.; Arad, S.M.; Bitton, R. The sulfated polysaccharide from a marine red microalga as a platform for the incorporation of zinc ions. Carbohydr. Polym. 2016, 152, 658-664. [CrossRef]

76. Bernaerts, T.M.M.; Kyomugasho, C.; Looveren, N.V.; Gheysen, L.; Foubert, I.; Hendrickx, M.E.; Loey, A.M.V. Molecular and rheological characterization of different cell wall fractions of Porphyridium cruentum. Carbohydr. Polym. 2018, 195, 542-550. [CrossRef] [PubMed]

77. Behrouzian, F.; Razavi, S.M.; Karazhiyan, H. Intrinsic viscosity of cress (Lepidium sativum) seed gum: Effect of salts and sugars. Food Hydrocoll. 2014, 35, 100-105. [CrossRef]

78. Rachidi, F.; Benhima, R.; Sbabou, L.; Arroussi, H.E. Microalgae polysaccharides bio-stimulating effect on tomato plants: Growth and metabolic distribution. Biotechnol. Rep. 2020, 25, e00426. [CrossRef] [PubMed]

79. Cunha, C.; Silva, L.; Paulo, J.; Faria, M.; Nogueira, N.; Cordeiro, N. Microalgal-based biopolymer for nano- and microplastic removal: A possible biosolution for wastewater treatment. Environ. Pollut. 2020, 263, 114385. [CrossRef] 
80. Arad, S.M.; Levy-Ontman, O. Red microalgal cell-wall polysaccharides: Biotechnological aspects. Curr. Opin. Biotechnol. 2010, 21, 358-364. [CrossRef]

81. Pierre, G.; Delattre, C.; Dubessay, P.; Jubeau, S.; Vialleix, C.; Cadoret, J.-P.; Probert, I.; Michaud, P. What Is in Store for EPS Microalgae in the Next Decade? Molecules 2019, 24, 4296. [CrossRef] 